Central Washington University

ScholarWorks@CWU

Geological Sciences Faculty Scholarship

College of the Sciences

$1-1-2016$

\title{
Black Carbon Concentrations from a Tibetan Plateau Ice Core Spanning 1843-1982: Recent Increases due to Emissions and Glacier Melt
}

Susan Kaspari

Central Washington University, susan.kaspari@cwu.edu

Matthew Jenkins

Shi-Chang Kang

Bjorn Grigholm

Follow this and additional works at: https://digitalcommons.cwu.edu/geological_sciences

Part of the Geology Commons

\section{Recommended Citation}

Matthew, Susan, Kang, Bjorn, \& Paul A. (2016). Tibetan Plateau Geladaindong black carbon ice core record (1843-1982): Recent increases due to higher emissions and lower snow accumulation. Advances in Climate Change Research, 7(3), 132-138.

This Article is brought to you for free and open access by the College of the Sciences at ScholarWorks@CWU. It has been accepted for inclusion in Geological Sciences Faculty Scholarship by an authorized administrator of ScholarWorks@CWU. For more information, please contact pingfu@cwu.edu. 
Black carbon concentrations from

Black carbon concentrations from a Tibetan Plateau ice core spanning 1843-1982: recent increases due to emissions and glacier melt

a Tibetan Plateau ice

core

M. Jenkins et al.

Title Page

Abstract

Conclusions

Tables

14

Back
Introduction

References

Figures

$\Delta$

Close

Received: 23 August 2013 - Accepted: 13 September 2013 - Published: 1 October 2013

Correspondence to: S. Kaspari (kaspari@geology.cwu.edu)

Full Screen / Esc

Published by Copernicus Publications on behalf of the European Geosciences Union.

Interactive Discussion 


\section{Abstract}

Black carbon (BC) deposited on snow and glacier surfaces can reduce albedo and lead to accelerated melt. An ice core recovered from Guoqu glacier on Mt. Geladaindong and analyzed using a Single Particle Soot Photometer provides the first long-term

5 (1843-1982) record of BC concentrations from the Central Tibetan Plateau. The highest concentrations are observed from 1975-1982, which corresponds to a 2.0-fold and 2.4-fold increase in average and median values, respectively, relative to 1843-1940. $\mathrm{BC}$ concentrations post-1940 are also elevated relative to the earlier portion of the record. Causes for the higher $\mathrm{BC}$ concentrations include increased regional $\mathrm{BC}$ emisand subsequent deposition, and melt induced enrichment of $B C$, with the melt potentially accelerated due to the presence of $\mathrm{BC}$ at the glacier surface. A qualitative comparison of the $\mathrm{BC}$ and $\mathrm{Fe}$ (used as a dust proxy) records suggests that if changes in the concentrations of absorbing impurities at the glacier surface have influenced recent glacial melt, the melt may be due to the presence of $\mathrm{BC}$ rather than dust. Guoqu glacier has received no net ice accumulation since the 1980s, and is a potential example of a glacier where an increase in the equilibrium line altitude is exposing buried high impurity layers. That BC concentrations in the uppermost layers of the Geladaindong ice core are not substantially higher relative to deeper in the ice core suggests that some of the BC that must have been deposited on Guoqu glacier via wet or dry deposition between 1983 and 2005 has been removed from the surface of the glacier, potentially via supraglacial or englacial meltwater.

\section{Introduction}

Black carbon (BC), an aerosol produced by the incomplete combustion of fossil and bio-fuels, can impact climate by absorbing energy directly in the atmosphere and by reducing albedo when deposited on snow and ice, potentially enhancing melt and accelerating glacial retreat (Hansen and Nazarenko, 2004). The study of BC's past and
Black carbon concentrations from

a Tibetan Plateau ice core

M. Jenkins et al.

Title Page

Abstract Introduction

Conclusions

Tables References

Figures

14

$\Delta \mathbf{I}$

4

Back

$\rightarrow$

Close

Full Screen / Esc

Printer-friendly Version

Interactive Discussion 
present variability is imperative in order to better understand and estimate its potential impacts on climate and water resources. This is especially important in the Himalaya/Tibetan Plateau, a region that provides fresh water to over a billion people and where BC's climatic effects are estimated to be the largest (Flanner et al., 2007; Ra5 manathan and Carmichael, 2008; Qian et al., 2011). Research regarding BC deposition on snow and ice in the Tibetan Plateau and Himalaya has increased in recent years, although the majority of these studies have been limited to spatial variations in surface snow (Ming et al., 2009), or relatively short-term temporal variations of BC concentrations since 1950 reconstructed from ice cores (Liu et al., 2008; Ming et al., 2008; Xu et 10 al., 2009). Longer-term (pre-industrial to present) records of BC are useful for assessing BC's impact on historic climate, and establishing background BC concentrations before industrialization (Kaspari et al., 2011). Additionally, BC has a short atmospheric residence time (days to weeks), which means that BC's impacts are highly correlated to its sources, requiring records from many locations. Ice cores from mountain glaciers prove useful in reconstructing past $\mathrm{BC}$ concentrations. Presented here is the first longterm record (1843-1982) of BC concentrations from the central Tibetan Plateau, reconstructed from an ice core recovered from Mt. Geladaindong (5800 m a.s.I.) and analyzed at high-resolution using a Single Particle Soot Photometer (SP2; Droplet Measurement Technologies, Boulder, USA).

\section{Methods}

In Fall 2005, a $147 \mathrm{~m}$ long ice core was recovered from Guoqu glacier on the northern slope of Mt. Geladaindong ( $33^{\circ} 34.60^{\prime} \mathrm{N}, 91^{\circ} 10.76^{\prime} \mathrm{E}, 5750 \mathrm{~m}$ a.s.l.) located in the Tanggula Mountains of the central Tibetan Plateau (Kang et al., 2013) (Fig. 1). The ice core was collected using an electro-mechanical drill during an expedition led by the Institute of Tibetan Plateau Research. A quarter section of the $147 \mathrm{~m}$ ice core was processed in May 2010 in Lanzhou, China at the Cold and Arid Regions Environmental and Engineering Research Institute, in preparation for BC analysis. The core was cut

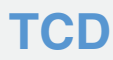

$7,4855-4880,2013$

Black carbon

concentrations from

a Tibetan Plateau ice

core

M. Jenkins et al.

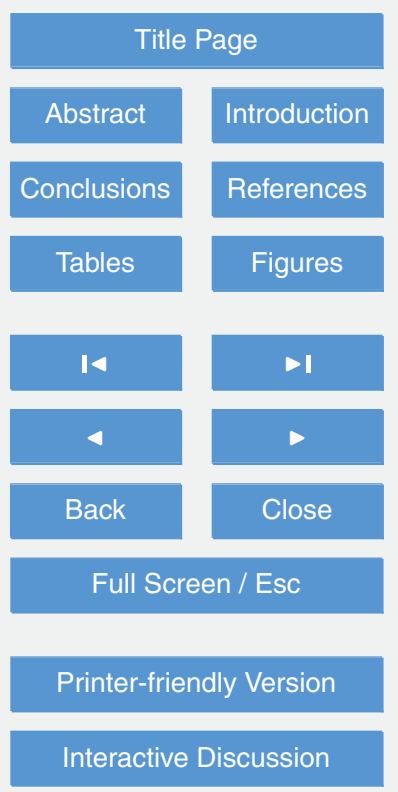


into $\sim 5-6.5 \mathrm{~cm}$ segments and rinsed in ultra-pure Milli-Q water to remove the outer section of the core that can potentially be contaminated during the drilling or cutting process. Once rinsed, samples were placed in $50 \mathrm{~mL}$ polypropylene vials and prepared for shipment to Central Washington University in Ellensburg, WA. Due to customs is5 sues the samples were not kept frozen. Because earlier tests showed that refreezing samples resulted in an apparent reduction in BC concentrations (Kaspari et al., 2011), the samples were stored as liquid until analyzed for BC using a Single Particle Soot Photometer (SP2) between October 2010 and July 2011.

All samples were treated and analyzed for $\mathrm{BC}$ according to the methods reported 10 by Kaspari et al. (2011): samples were acidified to $0.5 \mathrm{~mol} \mathrm{HNO}_{3}$, sonicated for $15 \mathrm{~min}$ just prior to analysis, and stirred using a magnetic stirrer during analysis. Subsequent research has shown that acidification aids in recovery of $B C$ in samples stored in polypropylene (Wendl et al., 2013), however in general we advise against acidification for samples that are kept frozen until just prior to analysis because acidification 15 can cause a shift towards smaller BC particles (Schwarz et al., 2012). The liquid samples were nebulized using a Cetac U-5000AT+ ultrasonic nebulizer, and the resulting aerosol was coupled to the inlet of the SP2. The SP2 uses laser-induced incandescence to determine the mass of refractory $B C$ in individual particles (Schwarz et al., 2006; Stephens et al., 2003). The SP2 at CWU was internally calibrated using 20 Aquadag. Monitoring of liquid sample flow rate pumped into the nebulizer, fraction of liquid sample nebulized and purge airflow rate allows BC mass concentrations in the liquid sample to be determined. Schwarz et al. (2012) report that the SP2 combined with a Collison-type nebulizer can be used to measure BC mass concentration in snow with an estimated $60 \%$ uncertainty (due to uncertainty in calibration results, and size dependent nebulization efficiency). The $\mathrm{BC}$ concentrations reported herein underestimate actual concentrations, and have a higher uncertainty than $60 \%$ due to the following:

- Loss of BC particles in the Cetac U-5000AT+ ultrasonic nebulizer. Schwarz et al. (2012) tested nebulization efficiency based on particle size using polystyrene latex spheres ranging in size between 220 and $1537 \mathrm{~nm}$, and reported that the 4858

TCD

$7,4855-4880,2013$

Black carbon

concentrations from

a Tibetan Plateau ice

core

M. Jenkins et al.

Title Page

Abstract

Introduction

Conclusions

Tables

References

Figures

14

$>$ I

4

Back

$\checkmark$

Close

Printer-friendly Version

Interactive Discussion 
Cetac nebulization efficiency was size dependent. The nebulization efficiency was $20 \%$ or less for particles greater than $700 \mathrm{~nm}$ relative to particles in the 200-500 nm size range. Subsequent research at CWU confirmed the results of Schwarz for the Cetac, while Wendl et al. (2013) found that nebulization efficiency was greatest in the 300-400 $\mathrm{nm}$ size range, with decreased efficiency for smaller and larger particle sizes. Additionally,Schwarz et al. (2013) report larger mass size distributions of $\mathrm{BC}$ in snow than $\mathrm{BC}$ in the atmosphere, with the mass of $\mathrm{BC}$ cores larger than $600 \mathrm{~nm}$ accounting for $17 \%$ or more of the $\mathrm{BC}$ mass based on snow samples in Colorado. Thus, a non-trivial mass of $B C$ is not nebulized by the Cetac nebulizer, and thus not measured by the SP2. We correct for the mass of $\mathrm{BC}$ not nebulized based on gravimetric Aquadag standard solutions (assuming $70 \%$ of the dry content of Aquadag is BC). This standard correction does not fully address the size dependent nebulization nor likely differences in the mass-size distributions of Aquadag and the snow samples. We also note that prior studies using the SP2 to measure BC concentrations in liquid samples have used other $\mathrm{BC}$ materials as a calibration standard, with other standards resulting in a higher corrected BC concentration than Aquadag (Wendl et al., 2013)

- Apparent BC losses during sample storage. As stated above, the Geladaindong samples were not kept frozen, thus we have sought to quantify changes that can occur to the sample during storage in the liquid phase. Freshly prepared Aquadag standards and environmental snow melted just prior to being measured were remeasured periodically over a 212-day period (Wendl et al., 2013). Measured BC concentrations decreased until 55 days, after which BC concentrations stabilized. Possible causes of the $\mathrm{BC}$ losses include $\mathrm{BC}$ adhering to the vial walls, and/or $\mathrm{BC}$ particles agglomerating above the size range at which particles are efficiently nebulized and outside of the detection range of the SP2. BC losses are proportionally greater in low concentration samples relative to higher concentration samples, however the decrease in measured BC mass is slightly larger in the higher concentration samples relative to the lower concentration samples. The implica-

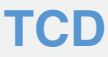

$7,4855-4880,2013$

Black carbon concentrations from

a Tibetan Plateau ice core

M. Jenkins et al.

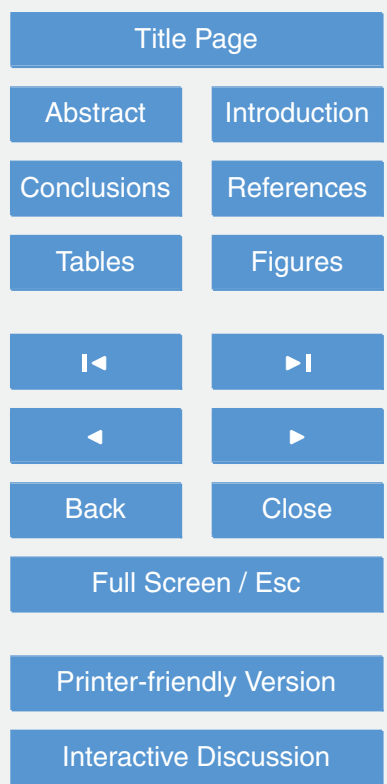


tion for the results presented herein is that relative trends are preserved in the samples that were stored in the liquid phase. However, the difference observed between low and high BC concentration samples is less than was likely preserved in the un-melted ice, and the increase factors that we report below are underestimates. This is supported by Menking et al. (2013) who used the SP2 to measure $\mathrm{BC}$ concentrations in samples from a Mt. Logan ice core that had been stored in the liquid state at room temperature for numerous years, and in $8 \mathrm{~m}$ of archived ice that was melted just prior to analysis (the liquid and frozen samples are from the same depths of adjacent slabs from the same ice core). The two BC records showed the same trends and were significantly correlated, although BC concentrations were approximately a magnitude higher in the freshly melted ice as anticipated. In addition, the relative difference between high and low concentration samples was greater in the freshly melted samples than the stored liquid samples, confirming our suggestion that increase factor analyses will underestimate actual concentration changes for samples that have been stored in the liquid phase. All of the samples presented in this study were analyzed between five and fourteen months after being melted, and $\mathrm{BC}$ concentrations are assumed to have reached equilibrium based on our storage experiments.

These factors lead to large uncertainties in the actual BC concentrations, with the data 20 reported herein representing lower limit values. As a result, we report the $B C$ concentrations as measured $\mathrm{BC}(\mathrm{M} B \mathrm{BC})$, and focus our interpretation on relative differences in $\mathrm{BC}$ rather than on absolute concentrations. Note that the concentrations reported herein predominantly represent the mass of BC particles $500 \mathrm{~nm}$ and smaller, which corresponds to the size range where the mass absorption cross section of $\mathrm{BC}$ particles is greater relative to larger particles, meaning that smaller BC particles absorb light and reduce albedo more efficiently (Schwarz et al., 2013). Despite the uncertainties in the data, the ${ }_{M} B C$ data yield information that furthers our understanding of $B C$ temporal variations and impacts on the Tibetan Plateau.

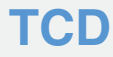

$7,4855-4880,2013$

Black carbon

concentrations from

a Tibetan Plateau ice

core

M. Jenkins et al.

Title Page

Abstract

Introduction

Conclusions

Tables

References

Figures

14

$\rightarrow I$

4

Back

$\triangleright$

Close

Full Screen / Esc

Printer-friendly Version

Interactive Discussion 
Other sections of the ice core have been previously sampled and analyzed for soluble major ions by ion chromatography, for trace elements by inductively coupled plasma mass spectrometry, and $\delta^{18} \mathrm{O}$ by mass spectrometry, all performed at the Climate Change Institute of the University of Maine (Grigholm et al., 2013). The ice core was 5 dated by counting the annual layer signal from isotopes, ions, and trace elements, and verified using known age horizons from tritium that peak in $1963,{ }^{210} \mathrm{~Pb}$ and several volcanic markers (Kang et al., 2013). Although the ice core was recovered in 2005, annual mass loss of ice at this location has resulted in the loss of the most recent $22 \mathrm{yr}$ of the record, and the top of the core is dated to 1982 AD (Kang et al., 2013). To account 10 for changes in sample resolution with depth in the ice core due to glacier thinning, the high-resolution ${ }_{M} \mathrm{BC}$ and $\mathrm{Fe}$ (used as a proxy for dust) data were re-sampled to three samples per year.

\section{Results and discussion}

\subsection{Results}

15 Six-hundred and twenty-five samples were analyzed for BC from the upper $42 \mathrm{~m}$ of the core, providing a record of ${ }_{M} B C$ concentrations from the central Tibetan Plateau from 1843-1982 (Fig. 2). The record is characterized by an increase in $M B C$ concentrations during the most recent period of the record: the highest concentrations are observed from 1975-1982, which corresponds to a 2.0-fold increase in average and

20 a 2.4-fold increase in median values relative to 1843-1940 (Table 1). Causes for the higher ${ }_{M} B C$ concentrations include increased emissions and subsequent deposition, and/or increased glacier melt. These factors are considered in more detail below.

\subsection{Increased BC emissions and deposition}

BC fossil fuel sources include the burning of coal, diesel, and gasoline for manufac- turing, transportation, heating and cooling, and power generation (Bond et al., 2004; 4861

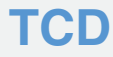

$7,4855-4880,2013$

Black carbon

concentrations from

a Tibetan Plateau ice

core

M. Jenkins et al.

Title Page

Abstract

Introduction

Conclusions

Tables

References

Figures

14

$\rightarrow I$

4

Back

$\triangleright$

Close

Full Screen / Esc

Printer-friendly Version

Interactive Discussion 
Reddy and Venkataraman, 2002a) while BC bio-fuel sources include forest fires, crop burning, and small-scale heating and cooking (Reddy and Venkataraman, 2002b; Venkataraman et al., 2005). Based on modeling work, Lu et al. (2012) found that BC deposited over the Tibetan Plateau comes primarily from the residential, industry and land 5 transport sectors, with deposition greatest during the non-summer monsoon months, consistent with BC in snow observations from the region (Ming et al., 2009; Kaspari et al., 2011).

Due to Geladaindong's remote location, emissions from local sources are likely minimal. Instead, we expect the majority of BC deposited here to be transported from large10 scale regional sources. Prior investigations have reported the geographical sources of $\mathrm{BC}$ transported to this region of the Tibetan Plateau. Xu et al. (2009) suggest that the Middle East and Europe are the primary sources, whereas using the GEOS-Chem model Kopacz et al. (2011) found that BC transported to this region originates primarily from China, India, Pakistan and the Middle East, with lesser contributions from Nepal, 15 Africa and Russia.

Estimated BC emissions from historical records of energy-related combustion (Bond et al., 2007) from East Asia, the Former USSR, Eastern Europe, South Asia, and the Middle East increased since the 1850s, with marked increases in all regions by the mid-1900s (Fig. 2). The timing of the increase in emissions is consistent with the rise in ${ }_{M} B C$ concentrations as recorded by the Geladaindong ice core, particularly when examining the smoothed ${ }_{M} B C$ record. This suggests that the higher $B C$ concentrations are due, at least in part, to rising emissions in the region, however we are not able to attribute the rise to a specific source region.

\subsection{Increased glacier melt}

25 In addition to rising emissions, increased melt on Guoqu glacier may also have contributed to the higher ${ }_{M} B C$ concentrations preserved in the Geladaindong ice core since $\sim$ 1940. Previous studies have documented concentration of impurities at the glacier surface due to mechanical trapping during conditions of melt or sublimation (Xu et al.,

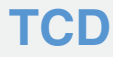

$7,4855-4880,2013$

Black carbon

concentrations from

a Tibetan Plateau ice

core

M. Jenkins et al.

Title Page

Abstract

Introduction

Conclusions

Tables

References

Figures

14

$>$ I

4

Back

$\triangleright$

Close

Full Screen / Esc

Printer-friendly Version

Interactive Discussion 
2012; Conway et al., 1996). Xu et al. (2012) monitored BC concentrations in the snowpack above the superimposed ice layer on a Tien Shan glacier over a year, and found that relative to freshly fallen snow, during the melt season BC was enriched in the surface snow and to an even greater extent in the snow/firn directly above the superim5 posed ice layer. Xu et al. propose that meltwater can flush BC through the upper $\sim 1 \mathrm{~m}$ of the snowpack. This results in lower BC concentrations in the snow between the surface and bottom depths of snow/firn, with BC unable to flow below the superimposed ice layer, resulting in build-up of $B C$ at this horizon.

To assess if melt induced enrichment in BC may have contributed to the increased 10 occurrence in layers of relatively high ${ }_{M} B C$ preserved in the Geladaindong ice core since the 1940s, we examine glacier variation and temperature data from the Geladaindong region. We also further consider the Geladaindong ice core record, as BC and other light absorbing impurities can not only become concentrated during melt, but also contribute to accelerated melt.

15 Glacier retreat in recent decades is widespread across the Tibetan Plateau (Yao et al., 2012). Specific to the Geladaindong region, Kang et al. (2013) show that Geladaindong $(5750 \mathrm{~m})$ and nearby Nyainqentanglha $(5850 \mathrm{~m})$ have not received net accumulation since the 1980s and 1950s, respectively. This indicates widespread melt in the region in recent decades, consistent with results previously reported in the Himalaya (Kehrwald et al., 2008). Ye et al. (2006) reconstructed glacier area in the Geladaindong region using topographic maps from 1969 and Landsat images from 1973-1976, 1992 and 2002. While some glaciers advanced during the time period investigated, the area of glacier retreat was much larger. During the period of overlap with the Geladaindong ice core, glacier area decreased by $4.7 \mathrm{~km}^{2}$ from 1969 to 1976 , followed by accelerated 25 glacier retreat during the $1980 \mathrm{~s}$ and $1990 \mathrm{~s}$.

Causes of glacier retreat are commonly attributed to rising temperatures (Barnett et al., 2005; Ye et al., 2006) reduction in accumulation due to atmospheric circulation changes (Yao et al., 2012), and deposition of light absorbing impurities including BC (Hansen and Nazarenko, 2004). Surface temperatures on the Tibetan Plateau have in-

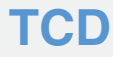

$7,4855-4880,2013$

Black carbon

concentrations from

a Tibetan Plateau ice

core

M. Jenkins et al.

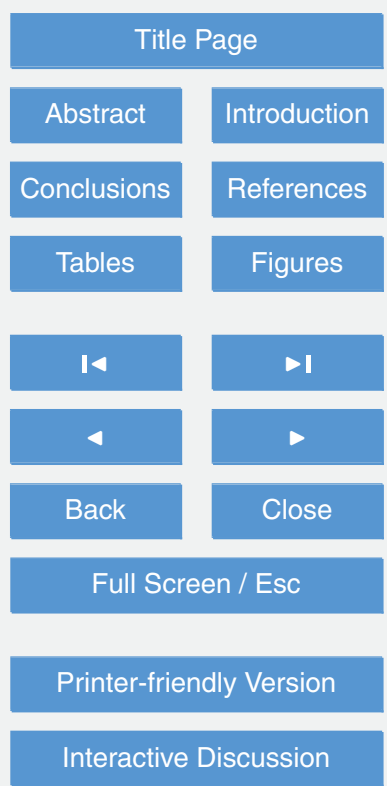


creased by $1.8^{\circ} \mathrm{C}$ since 1960 (Wang et al., 2008), with temperature increases greatest at high elevations (Liu and Chen, 2000). This temperature increase is roughly three times greater than the global average over the same time period. Deciphering the role of temperature induced melt in the Geladaindong region for the period of overlap with 5 the ice core record is challenging because few meteorological stations existed on the Tibetan Plateau prior to the 1950s, and stations from elevations greater than $4000 \mathrm{~m}$ are few. The longest temperature record from the region is from Natyn $\left(41^{\circ} 26^{\prime} \mathrm{N}, 76^{\circ} \mathrm{E}\right.$, $2049 \mathrm{~m}$ ), which goes back to 1886 . Natyn is characterized by rising temperatures since the 1950s, however prior warm periods occurred during the late 1890s, 1910s, and 10 1940s (Fig. 3). The lack of high ${ }_{M} B C$ concentrations during the 1890 s and 1910 s suggest that temperature induced melt may not be the dominant factor in causing ${ }_{M} B C$ enrichment in the Geladaindong core. However, these results are inconclusive since Natyn is relatively far from Geladaindong, and at a much lower elevation (Fig. 1). The closest temperature stations to Geladaindong are Tuotuohe $\left(34^{\circ} 13^{\prime}, 92^{\circ} 26^{\prime} \mathrm{E}, 4534 \mathrm{~m}\right)$ 15 and Anduo $\left(32^{\circ} 21^{\prime} \mathrm{N}, 91^{\circ} 6^{\prime} \mathrm{E}, 4801 \mathrm{~m}\right)$ with data going back to 1956 and 1965 , respectively (Figs. 1 and 3 ). There is not a significant correlation between temperature at these stations and ${ }_{M} B C$ concentrations in the ice core. This may be due to differences in temperature between the stations and Guoqu glacier, and likely other factors besides temperature that control both melt and $\mathrm{BC}$ concentrations.

20 Although glacier retreat is often attributed to temperature changes, glacier melt energy comes primarily from net solar radiation, which is controlled by irradiance and snow albedo (Oerlemans, 2000; Painter et al., 2007). Irradiance is primarily controlled by cloud cover and total optical depth (Ogunjobi et al., 2004), while snow albedo is controlled by light absorbing impurities (BC, dust, colored organics) in the visible waveductions in total and low-level cloud amounts during daytime over the Tibetan Plateau were documented over the 1961-2003 period (Duan and Wu, 2006), which would increase irradiance and hence melt energy. However, higher emissions of BC (Bond et al., 2007, Fig. 1) and other aerosols over the same period have likely increased the

TCD

$7,4855-4880,2013$

Black carbon

concentrations from

a Tibetan Plateau ice

core

M. Jenkins et al.

Title Page

Abstract

Introduction

Conclusions

Tables

References

Figures

14

$>$ I

4

Back

$\checkmark$

Close

Full Screen / Esc

Printer-friendly Version

Interactive Discussion 
aerosol optical depth over the Tibetan Plateau, which could counter the increased irradiance from cloud cover reductions. This is supported by observational data from the Tibetan Plateau showing a decrease in surface solar radiation from 1960-2009, with aerosol emissions identified as a plausible cause (You et al., 2013).

$5 \quad \mathrm{BC}$ and dust in snow and ice reduces the surface albedo, which heats the snowpack by conducting energy from the heated $\mathrm{BC}$ and dust to snow grains, resulting in accelerated snow metamorphism. This in turn leads to coarser snow grains, which further reduces the snow albedo (Painter et al., 2012). At Geladaindong, positive feedback cycles may exist in which (1) greater BC deposition has lowered the surface albedo and 10 increased melt, and/or (2) warmer temperatures have increased glacier melt, resulting in higher $\mathrm{BC}$ concentrations at the surface of the glacier from mechanical trapping, lower surface albedo, and increased melt. Thus, the higher ${ }_{M} B C$ concentrations observed since the 1940s may be caused by the combined effects of higher BC deposition on the glacier from increasing regional $\mathrm{BC}$ emissions, and melt induced enrichment of $\mathrm{BC}$, with the melt potentially accelerated due to the presence of $\mathrm{BC}$.

While many recent studies focus on the role of $B C$ in reducing snow albedo and accelerating snow and glacier melt in the region (e.g. Ming et al., 2008, 2009; Xu et al., 2009, 2012), less attention has been given to the efficacy of BC to reduce albedo and accelerate melt in the presence of other absorbing impurities. Albedo reductions from $\mathrm{BC}$ will be less in the presence of other absorbing impurities because the other impurities will capture some of the solar absorption that the BC would receive in the absence of other impurities (Kaspari et al., 2011). This is particularly relevant for glaciers in this region where the presence of other impurities can be high. In a modeling study Flanner et al. (2009) estimated that the Eurasian spring radiative forcing from BC and dust in snow is 2.7 and $1.2 \mathrm{~W} \mathrm{~m}^{-2}$, respectively. Kaspari et al. (2011) used BC and dust mass concentration and size distributions from an Everest ice core to estimate that the radiative forcing from $\mathrm{BC}$ exceeded that of dust, however large uncertainties in the optical properties of the dust along with the same BC analytical issues described in the methods above put these results in question. Wang et al. (2013) measured light-

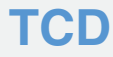

$7,4855-4880,2013$

Black carbon

concentrations from

a Tibetan Plateau ice

core

M. Jenkins et al.

Title Page

Abstract

Introduction

Conclusions

Tables

References

Figures

14

$\rightarrow I$

4

Back

$\checkmark$

Close

Full Screen / Esc

Printer-friendly Version

Interactive Discussion 
absorbing particles in snow across Northern China using a spectrophotometer, and found that snow particulate light absorption was dominated by $\mathrm{BC}$ in the northeast, whereas it was dominated by local soil and desert dust on the northern boundary of the Tibetan Plateau. Kaspari et al. (2013) measured BC and the total impurity load 5 in snow samples from Mera glacier in Nepal, and based on model results found that while $B C$ reduces albedo, dust dominates albedo reduction and the impact of $B C$ is diminished in the presence of dust.

Because the ${ }_{M} B C$ concentrations reported herein underestimate actual $B C$ concentrations in addition to uncertainties in the optical properties and absorption efficiency of dust in the Geladaindong ice core, we do not attempt to assess albedo reductions due to $B C$ and dust, nor the albedo reduction of $B C$ relative to dust. Instead, we examine trends in the ${ }_{\mathrm{M}} \mathrm{BC}$ and Fe records, using $\mathrm{Fe}$ as a proxy for dust because iron oxides dominate light absorption by mineral dust. From 1843 to $1982 \mathrm{MBC}$ and Fe display a close relationship, with peak concentrations commonly coinciding (Fig. 2). This 15 is likely due to: (1) the shared seasonality of $B C$ and dust, both of which display peak atmospheric concentrations during the winter/spring (Qian et al., 2009; Xu et al., 2009; Kaspari et al., 2011); (2) the mixing of aerosols and dust during long-distance transport; and (3) the mechanical trapping of impurities at the ablation surface during conditions of melting and sublimation (Conway et al., 1996; Xu et al., 2012). Although ${ }_{M} B C$ and $\mathrm{Fe}$ concentrations peak coincidentally, the Fe record does not display the same increase in maximum concentrations post-1940 as the ${ }_{M} B C$ record (Fig. 2). Rather, average concentrations of Fe decrease from 1843-1982 (Table 1). Because dust would undergo similar enrichment under melt conditions as BC, the lower Fe concentrations in the recent portion of the record suggest that either Fe deposition has decreased, or that $\mathrm{BC}$ deposition has increased associated with rising emissions. The different trends between the $\mathrm{BC}$ and Fe records further suggests that if changes in the concentrations of absorbing impurities have influenced recent glacial melt, it may be due to the presence of $\mathrm{BC}$ rather than dust. This conclusion is in agreement with the findings of Kaspari

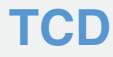

$7,4855-4880,2013$

Black carbon

concentrations from

a Tibetan Plateau ice

core

M. Jenkins et al.

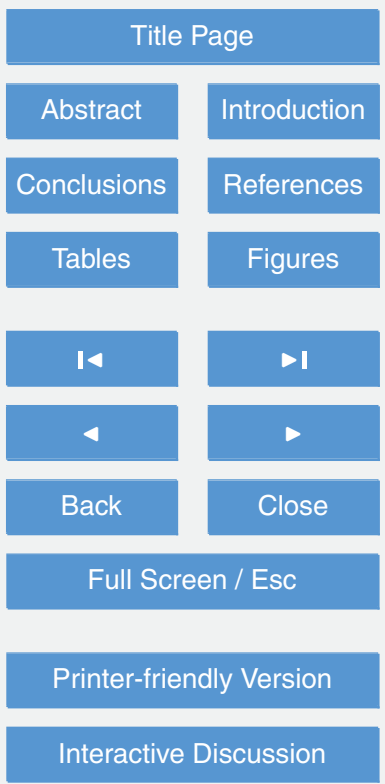


et al. (2011), who documented stable dust concentrations from 1860-2000 in the presence of increasing BC concentrations in a Mt. Everest ice core.

\subsection{Comparison to other Asian $\mathrm{BC}$ records}

There is interest in comparing the Geladaindong ${ }_{M} B C$ ice core record with other $B C$ 5 records from the region in regards to $\mathrm{BC}$ concentrations and trends, as this information has the potential to further understanding of the sources, transport, deposition and impacts of $B C$ in the region. Here we focus on a comparison of the Geladaindong ${ }_{M} B C$ ice core record with a $\mathrm{BC}$ record from a Tibetan Plateau lake sediment core (Cong et al., 2013), and with an Everest BC record (Kaspari et al., 2011). We focus on these 10 two records because they are the only $B C$ records from the region that span back to $\sim 1850$, and the Everest ice core was analyzed for BC by the same methods employed here.

BC flux in a sediment core from Nam Co Lake, Central Tibetan Plateau was relatively constant from 1857-1900, increased gradually from 1900-1960, and increased rapidly between 1960 and 2009 (Cong et al., 2013). The authors suggest that the rise in BC flux was most likely due to BC transported from South Asia. That the BC flux in the Nam Co core increases in recent decades supports that an increase in $B C$ concentrations at Geladaindong are due at least in part to higher $\mathrm{BC}$ emissions during the latter portion of the 20th century.

20 Samples from Geladaindong and Everest ice cores were stored for extended periods of time in the liquid phase. Based on the storage tests described previously, here we assume that $\mathrm{BC}$ losses during vial storage stabilized in both cores, and that a comparison of concentrations between the records provides a qualitative assessment of differences in $\mathrm{BC}$ concentrations. For the period of overlap between the two records

(1860-1982), $\mathrm{M}^{\mathrm{BC}}$ concentrations are more than threefold higher at Geladaindong than Everest, which may be due to differences in snow accumulation, atmospheric $\mathrm{BC}$ concentrations, elevation or melt (Table 2). The snow accumulation rate affects the resulting concentration of $\mathrm{BC}$ in snow. If two ice core sites differed only in their annual
$7,4855-4880,2013$

Black carbon concentrations from

a Tibetan Plateau ice core

M. Jenkins et al.

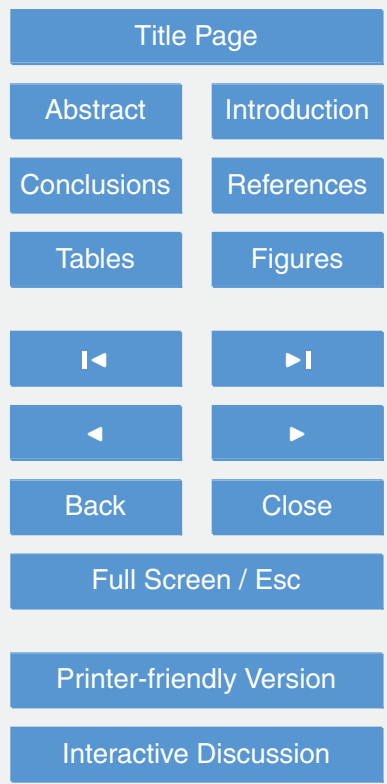


snow accumulation, the site with lower annual snow accumulation would display higher concentrations of $B C$ in snow. An approximate annual ${ }_{M} B C$ flux can be calculated by multiplying the accumulation rate at each site by its average or median ${ }_{M} B C$ concentration, which provides an approximate concentration of ${ }_{M} B C$ deposited $\left(\mathrm{ng} \mathrm{cm}^{-2}\right)$ each 5 year. The ${ }_{M} \mathrm{BC}$ flux is approximately two-fold higher at Geladaindong than Everest (Table 2), indicating that while differences in snow accumulation partially account for the difference in the $\mathrm{BC}$ concentrations, more $\mathrm{BC}$ is deposited at Geladaindong. We are limited in our ability to assess if differing atmospheric concentrations contributed to the difference in observed snow BC concentrations due to the lack of atmospheric ob10 servations. However, modeling results suggest that BC deposition would be greater at Everest than at Geladaindong due to the closer proximity of Everest to large S. Asian BC sources (Kopacz et al., 2011), although this analysis doesn't account for the elevation difference between the two sites. The lower elevation at Geladaindong is likely an important factor contributing to the higher ${ }_{M} B C$ concentrations. Previous studies have 15 documented higher BC concentrations in snow/ice at lower elevations relative to higher elevations (Ming et al., 2009; Wang et al., 2012; Kaspari et al., 2013). While higher atmospheric concentrations at lower altitudes may contribute to this trend, greater melt at lower elevations may have contributed to the higher BC deposition at Geladaindong. Thus we suggest that the higher ${ }_{M} B C$ concentrations at Geladaindong than Everest remelt that concentrates BC in the snowpack.

$\mathrm{BC}$ trends differ between Geladaindong and Everest. While ${ }_{\mathrm{M}} \mathrm{BC}$ increases post1940 at Geladaindong, the Everest record doesn't indicate a rise until the 1970s. The difference in the timing of the increase between the two sites probably reflects differrise in ${ }_{M} B C$ at Geladaindong due to rising emissions in E. Europe and the Former USSR, while the later rise at Everest is due to rising S. Asian emissions (Fig. 2).

We also compare average and median Fe concentrations between the two sites since this provides some information on the efficacy of the $\mathrm{BC}$ to reduce albedo in

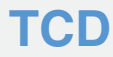

$7,4855-4880,2013$

Black carbon

concentrations from

a Tibetan Plateau ice

core

M. Jenkins et al.

Title Page

Abstract

Introduction

Conclusions

Tables

References

Figures

14

$\rightarrow 1$

4

Back

$\checkmark$

Close

Full Screen / Esc

Printer-friendly Version

Interactive Discussion 
the presence of other absorbing impurities. The Fe records from both ice cores are not affected by the methodological issues discussed earlier that apply to both ${ }_{M} B C$ records. Geladaindong Fe concentrations are 2.4-fold higher than at Everest, indicating higher dust deposition at Geladaindong and potentially reduced efficacy of BC to 5 lower the albedo at Geladaindong relative to Everest, even though ${ }_{M} B C$ concentrations at Geladaindong are more than threefold higher. However, as discussed previously, considerably more information is needed related to the dust optical properties, not to mention the limitations of the ${ }_{M} B C$ data presented herein, in order to evaluate the relative absorption of dust and $B C$ at both sites.

\subsection{Implications of Geladaindong BC record for glacier melt}

As discussed earlier, the relatively high ${ }_{M} B C$ concentrations in the most recent part of the Geladaindong ice core record have the potential to lead to or may have been caused by a positive feedback cycle, in which increased concentrations of $B C$ at the glacier surface lead to increased melt. Greater melt can further concentrate impurities, leading to further albedo reductions and melt. An exception to this process would be if the BC were flushed through the snowpack during high melt periods, as Xu et al. (2012) observed, or transported off the glacier with meltwater. The surface of Guoqu glacier consists of superimposed ice, which prevents the BC from being transported downwards in the glacier. That ${ }_{M} B C$ concentrations in the uppermost layers of the Geladaindong ice core are not markedly higher is notable. The most recent $22 \mathrm{yr}$ of accumulation were not preserved at the drill site on Guoqu glacier based on the ice core dating (Kang et al., 2013). If the glacier mass loss was causing numerous years of accumulated BC to coalesce into single horizons, we would expect to see higher BC concentrations than were observed in the upper layers of the ice core record. Because the observed

$\mathrm{BC}$ carbon increases in the upper layers of the ice core do not account for BC that must have been deposited on Guoqu glacier via wet or dry deposition between 1983 and when the ice core was drilled in 2005 , we suggest that some of the BC has been transported off the surface of the glacier, potentially via supraglacial or englacial flow.

TCD

$7,4855-4880,2013$

Black carbon concentrations from

a Tibetan Plateau ice core

M. Jenkins et al.

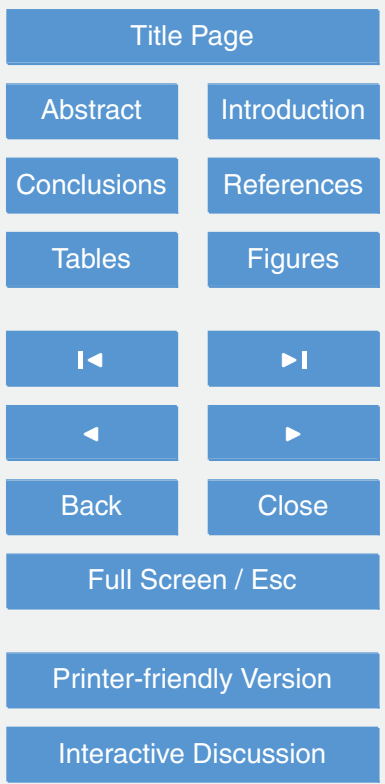


Xu et al. (2012) noted that due to the coupled impacts of greenhouse-gas warming and $\mathrm{BC}$ enrichment in surface snow, dirty ice that can at present form in the accumulation zone underlying the snowpack can be exposed in the future as the glacier equilibrium line altitude (ELA) increases. The ELA at Guoqu glacier has increased in recent 5 decades, thus this site is a potential example of the process that $\mathrm{Xu}$ et al. projects already occurring.

$\mathrm{BC}$ deposition on snow and glaciers remains a concern both for its radiative forcing effect, and its ability to affect glacier mass balance and the timing and availability of water resources (e.g., Hansen et al., 2004; Ramanathan and Carmichael, 2008). For ex10 ample, using a numerical model applied to BC observed on a Tibetan glacier, Yasunari et al. (2010) estimated that a 2.0-5.2\% albedo reduction could result in a 11.6-33.9\% increase in annual discharge if the reduced albedo snow layer remained at the glacier surface. While this increase in discharge likely overestimates actual increases in discharge since snow with a lower BC concentration and higher albedo can be deposited during the summer monsoon, it nevertheless highlights that $\mathrm{BC}$ has the potential to accelerate snow/ice melt, affecting the availability of water resources. Increased melt can thus lead to an increased supply of glacier runoff in the short term, but the concern for the future is extensive glacier retreat, resulting in a decreased availability of water resources.

\section{Conclusions}

Here we presented the first long-term (1843-1982) record of BC concentrations from the Tibetan Plateau reconstructed from a Mt. Geladaindong ice core. The record is characterized by an increase in $\mathrm{BC}$ concentrations during the most recent period of the record, with median $\mathrm{BC}$ concentrations from 1975-1982 more than twofold greater relative to 1843-1940. The higher BC concentrations in recent decades are likely caused by a combination of increased emissions from regional BC sources, and melt induced

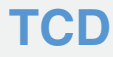

$7,4855-4880,2013$

Black carbon

concentrations from

a Tibetan Plateau ice

core

M. Jenkins et al.

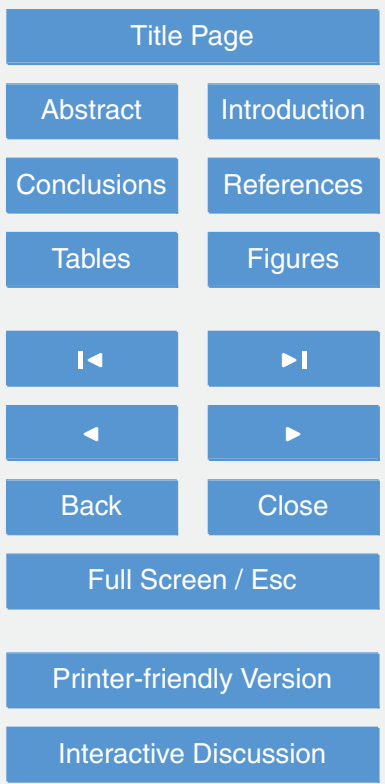


enrichment of $\mathrm{BC}$, with the melt potentially accelerated due to the presence of $\mathrm{BC}$ at the glacier surface.

Guoqu glacier on Mt. Geladaindong serves as a potential example of a glacier where an increase in the ELA is already exposing buried high impurity layers. Because the 5 most recent $22 \mathrm{yr}$ (1983-2005) of accumulation were not preserved at the drill site on Guoqu glacier, it is notable that $\mathrm{BC}$ concentrations in the uppermost layers of the Geladaindong ice core are not markedly higher. This suggests that some of the BC that must have been deposited on Guoqu glacier via wet or dry deposition between 1983 and 2005 has been removed from the surface of the glacier, potentially via supraglacial or englacial meltwater.

The available $B C$ and dust data are not sufficient to quantify the relative absorption of $B C$ versus dust to albedo reductions. However, that dust concentrations are lower in recent decades suggest that if changes in the concentrations of absorbing impurities have influenced recent glacial melt, the melt may be due to the presence of $\mathrm{BC}$ rather than dust. Further observational studies are needed to assess the relative contribution of different absorbing impurities (e.g., BC, dust, colored organics, humic-like substances, snow algae) to snow and glacier melt.

Acknowledgements. This research was funded by the National Science Foundation (OISE0653933 and EAR-0957935) and by a Geological Society of America Graduate Research

\section{References}

Barnett, T. P., Adam, J. C., and Lettenmaier, D. P.: Potential impacts of a warming climate on water availability in snow-dominated regions, Nature, 438, 303-309, doi:10.1038/nature04141, 2005.

25 Bond, T. C., Streets, D. G., Yarber, K. F., Nelson, S. M., Woo, J.-H., and Klimont, Z.: A technology-based global inventory of black and organic carbon emissions from combustion, J. Geophys. Res., 109, D14203, doi:10.1029/2003JD003697, 2004.

Black carbon concentrations from

a Tibetan Plateau ice

core

M. Jenkins et al.

Title Page

Abstract

Conclusions

Tables

14

4

Back

Full Screen / Esc

Printer-friendly Version 
Bond, T. C., Bhardwaj, E. , Dong, R., Jogani, R., Jung, S., Roden, C., Streets, D. G., and Trautmann, N. M.: Historical emissions of black and organic carbon aerosol from energy-related combustion, 1850-2000, Global Biogeochem. Cycles, 21, GB2018, doi:10.1029/2006GB002840, 2007.

5 Cong, Z., Kang, S., Gao, S., Zhang, Y., Li, Q., and Kawamura, K.: Historical trends of atmospheric black carbon on Tibetan Plateau as reconstructed from a 150-Year lake sediment record, Environ. Sci. Tech., 47, 2579-2586, 2013.

Conway, H., Gades, A., and Raymond, C. F.: Albedo of dirty snow during conditions of melt, Water Resour. Res., 32, 1713-1718, 1996.

10 Duan, A., and Wu, G.: Change of cloud amount and the climate warming on the Tibetan Plateau, Geophys. Res. Lett., 33, L22704, doi:10.1029/2006GL027946, 2006.

Flanner, M. G., Zender, C. S., Randerson, J. T., and Rasch, P. J.: Present-day climate forcing and response from black carbon in snow, J. Geophys. Res., 112, D11202, doi:10.1029/2006JD008003,2007.

Flanner, M. G., Zender, C. S., Hess, P. G., Mahowald, N. M., Painter, T. H., Ramanathan, V., and Rasch, P. J.: Springtime warming and reduced snow cover from carbonaceous particles, Atmos. Chem. Phys., 9, 2481-2497, doi:10.5194/acp-9-2481-2009, 2009.

Hansen, J. and Nazarenko, L.: Soot climate forcing via snow and ice albedos, P. Natl. Acad. Sci., 101, 423-428, 2004.

20 Kang, S., Wang, F., Morgenstern, U., Zhang, Y., Grigholm, B., Kaspari, S., Ren, J., Yao, T., Qin, D., Schwikowski, M., and Mayewski, P. A.: Dramatic thinning of high-elevation glaciers in the Tibetan Plateau revealed by ice core tritium and mercury records, Geophys. Res. Lett., 2013.

Kaspari, S., Schwikowski, M., Gysel, M., Flanner, M. G., Kang, S., Hou, S., and Mayewski, P. A.: Recent increase in black carbon concentrations from a Mt. Everest ice core spanning 1860-2000 AD, Geophys. Res. Lett., 38, L04703, doi:10.1029/2010GL046096, 2011.

Kaspari, S., Schwikowski, M., Gysel, M., and Painter, T. H.: Seasonal and elevational variations in black carbon and dust concentrations in snow and ice in the Solu-Khumbu, Nepal, Atmos. Chem. Phys., 2013.

so Kehrwald, N., Thompson, L. G., Yao, T., Mosley-Thompson, E., Schotterer, U., Alfimov, V., Beer, J., Eikenberg, J., and Davis, M.: Mass loss on Himalayan glacier endangers water resources, Geophys. Res. Lett., 35, L22503, doi:10.1029/2008GL035556, 2008.

Black carbon

concentrations from

a Tibetan Plateau ice

core

M. Jenkins et al.

Title Page

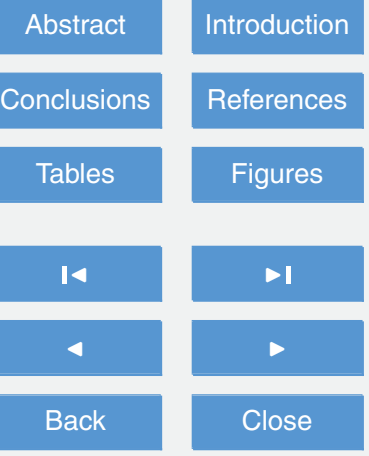

Full Screen / Esc

Printer-friendly Version

Interactive Discussion 
Kopacz, M., Mauzerall, D. L., Wang, J., Leibensperger, E. M., Henze, D. K., and Singh, K.: Origin and radiative forcing of black carbon transported to the Himalayas and Tibetan Plateau, Atmos. Chem. Phys., 11, 2837-2852, doi:10.5194/acp-11-2837-2011, 2011.

Liu, X. D. and Chen, B. D.: Climatic warming in the Tibetan Plateau during recent decades, Int. J. Climatol., 20, 1729-1742, 2000.

Liu, X., Xu, B., Yao, T., Wang, N., and Wu, G.: Carbonaceous particles in Muztag Ata ice core, West Kunlun Mountains, China, Chinese Sci. Bull., 53, 3379-3386, 2008.

Menking, J. A., Kaspari, S., and Osterberg, E. C.: An 1852-1999 ice core record of black carbon from Mount Logan, Yukon Territory, Canada, in preparation, 2013.

10 Ming, J., Cachier, H., Xiao, C., Qin, D., Kang, S., Hou, S., and Xu, J.: Black carbon record based on a shallow Himalayan ice core and its climatic implications, Atmos. Chem. Phys., 8 , 1343-1352, doi:10.5194/acp-8-1343-2008, 2008.

Ming, J., Xiao, C., Cachier, H., Qin, D., Qin, X., Li, Z., and Pu, J.: Black Carbon (BC) in the snow of glaciers in west China and its potential effects on albedos, Atmos. Res., 92, 114$15 \quad 123,2009$.

Oerlemans, J.: Analyis of a three-year meteorological record from the ablation zone of the Morteratschgletscher, Switzerland: energy and mass balance, J. Glaciol., 46, 571-579, 2000.

Ogunjobi, K. O., Kim, Y. J., and He, Z.: Influence of the total atmospheric optical depth and cloud cover on solar irradiance components, Atmos. Res., 70, 209-227, 2004.

Painter, T., Barrett, A. P., Landry, C. C., Neff, J. C., Cassidy, M. P., Lawrence, C. R., McBride, K. E., and Farmer, G. L.: Impact of disturbed desert soils on duration of mountain snow cover, Geophys. Res. Lett., 34, L12502 doi:10.1029/ 2007GL030284, 2007.

Painter, T., Skiles, S. M., Deems, J., Bryant, A., and Landry, C.: Dust radiative forcing in snow of the Upper Colorado River Basin: 1. A 6 year record of energy balance, radiation, and dust concentrations, Water Resour. Res., 48, W07521, doi:10.1029/2012WR011986, 2012.

Qian, Y., Flanner, M. G., Leung, L. R., and Wang, W.: Sensitivity studies on the impacts of Tibetan Plateau snowpack pollution on the Asian hydrological cycle and monsoon climate, Atmos. Chem. Phys., 11, 1929-1948, doi:10.5194/acp-11-1929-2011, 2011.

30 Ramanathan, V. and Carmichael, G. R.: Global and regional climate changes due to black carbon, Nat. Geosci., 1, 221-227, 2008.

Reddy, M. S. and Venkataraman, C.: Inventory of aerosol and sulphur dioxide emissions from India: I-Fossil fuel combustion, Atmos. Environ., 36, 677-697, 2002a.
TCD

7, 4855-4880, 2013

Black carbon

concentrations from

a Tibetan Plateau ice

core

M. Jenkins et al.

Title Page

Abstract

Introduction

Conclusions

Tables

References

Figures

14

4

Back

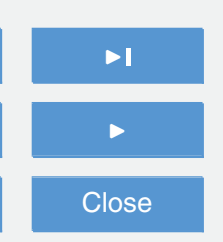

Full Screen / Esc

Printer-friendly Version

Interactive Discussion 
Reddy, M. S. and Venkataraman, C.: Inventory of aerosol and sulphur dioxide emissions from India. Part II-Biomass combustion, Atmos. Environ., 36, 699-712, 2002b.

Schwarz, J. P., Gao, R. S., Fahey, D. W., Thomson, D. S., Watts, L. A., Wilson, J. C., Reeves, J. M., Darbeheshti, M., Baumgardner, D. G., Kok, G. L., Chung, S. H., Schulz, M., Hendricks, $5 \quad$ J., Lauer, A., Kärcher, B., Slowik, J. G., Rosenlof, K. H., Thompson, T. L., Langford, A. O., Loewenstein, M., and Aikin, K. C.: Single-particle measurements of midlatitude black carbon and light-scattering aerosols from the boundary layer to the lower stratosphere, J. Geophys. Res., 111, D16207, doi:10.1029/2006JD007076, 2006.

Schwarz, J. P., Doherty, S. J., Li, F., Ruggiero, S. T., Tanner, C. E., Perring, A. E., Gao, R. S., and Fahey, D. W.: Assessing Single Particle Soot Photometer and Integrating Sphere/Integrating Sandwich Spectrophotometer measurement techniques for quantifying black carbon concentration in snow, Atmos. Meas. Tech., 5, 2581-2592, doi:10.5194/amt-5-2581-2012, 2012.

Schwarz, J. P., Gao, R. S., Perring, A. E., Spackman, J. R., and Fahey, D. W.: Black carbon aerosol size in snow, Nature Scientific Reports, 3, 1356, doi:10.1038/srep01356, 2013.

15 Stephens, M., Turner, N., and Sandberg, J.: Particle identification by laser-induced incandescence in a solid-state laser cavity, Appl. Optics, 42, 3726-3736, 2003.

Venkataraman, C., Habib, G., Eiguren-Fernandez, A., Miguel, A. H., and Friedlander, S. K.: Residential biofuels in south Asia: Carbonaceous aerosol emissions and climate impacts, Science, 307, 1454-1456, doi:10.1126/science.1104359, 2005.

Wang, B., Bao, Q., Hoskins, B., Wu, G., and Liu, Y.: Tibetan Plateau warming and precipitation changes in East Asia, Geophys. Res. Lett., 35, L14702, doi:10.1029/2008GL034330, 2008.

Wang, M., Xu, B., Zhao, H., Cao, J., Joswiak, D., Wu, G., and Lin, S.: The Influence of Dust on Quantitative Measurements of Black Carbon in Ice and Snow when Using a Thermal Optical Method, Aerosol Sci. Tech., 46, 60-69, 2012.

Wang, X., Doherty, S., and Huang, J.: Black carbon and other light-absorbing impurities in snow across Northern China, J. Geophys. Res., 118, 1471-1492, doi:10.1029/2012JD018291, 2013.

Wendl, I., Menking, J. A., Farber, Gysel, M., Kaspari, S., Laborde, M., and Schwikowski, M.: Optimized method for black carbon analysis in ice and snow, Environ. Sci. Technol., 2013.

so Xu, B., Cao, J., Hansen, J., Yao, T., Joswiak, D., Wang, N., Wu, G., Wang, M., Zhao, H., Yang, W., Liu, X., and He, J.: Black soot and the survival of Tibetan glaciers, P. Natl. Acad. Sci., 106, 22114-22118, 2009.

\section{TCD}

7, 4855-4880, 2013

Black carbon

concentrations from

a Tibetan Plateau ice

core

M. Jenkins et al.

Title Page

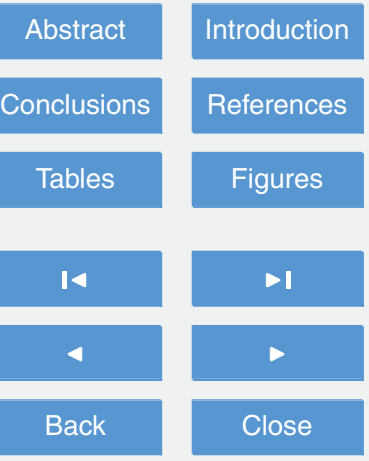

Full Screen / Esc

Printer-friendly Version

Interactive Discussion 
Xu, B., Cao, J., Joswiak, D., Liu, X., Zhao, H., and He, J.: Post-depositional enrichment of black soot in snow-pack and accelerated melting of Tibetan glaciers, Environ. Res. Lett., 7, 2211422118, 014022, 2012.

Yao, T., Thompson, L. G., Yang, W., Yu, W., Gao, Y., Guo, X., Yang, X. G., Duan, K., Zhao, $5 \quad$ H., Xu, B., Pu, J., Lu, A., Xiang, Y., Kattel, D., and Joswiak, D.: Different glacier status with atmospheric circulations in Tibetan Plateau and surroundings, Nature Climate Change, 2, 663-667, 2012.

Yasunari, T. J., Bonasoni, P., Laj, P., Fujita, K., Vuillermoz, E., Marinoni, A., Cristofanelli, P., Duchi, R., Tartari, G., and Lau, K.-M.: Estimated impact of black carbon deposition during pre-monsoon season from Nepal Climate Observatory-Pyramid data and snow albedo changes over Himalayan glaciers, Atmos. Chem. Phys., 10, 6603-6615, doi:10.5194/acp10-6603-2010, 2010.

Ye, Q., Kang, S., Chen, F., and Wang, J.: Monitoring glacier variations on Geladandong mountain, central Tibetan Plateau, from 1969 to 2002 using remote-sensing and GIS technologies, J. Glaciol., 52, 537-545, 2006.

You, Q., Sanchez-Lorenzo, A., Wild, M., Folini, D., Fraedrich, K., Ren, G., and Kang, S.: Decadal variation of surface solar radiation in the Tibetan Plateau from observations, reanalysis and model simulations, Clim. Dynam., 40, 2073-2086, 2013.

Black carbon

concentrations from

a Tibetan Plateau ice

core

M. Jenkins et al.

Title Page

Abstract

Introduction

Conclusions

References

Tables

Figures

14

$>1$

4

Back

Full Screen / Esc

Printer-friendly Version

Interactive Discussion 
Black carbon concentrations from

a Tibetan Plateau ice core

M. Jenkins et al.

Table 1. Geladaindong average and (median) Fe and ${ }_{M} B C$ concentrations $\left(\mu \mathrm{L} \mathrm{L}^{-1}\right)$ and increase factors based on data resampled to 3 samples/year.

\begin{tabular}{llllll}
\hline & $1843-1940$ & $1940-1982$ & $1975-1982$ & $\begin{array}{l}1940-1982 / \\
1843-1940\end{array}$ & $\begin{array}{l}1975-1982 / \\
1843-1940\end{array}$ \\
\hline $\mathrm{M}^{\mathrm{BC}}$ & $1.7(1.2)$ & $2.9(1.5)$ & $3.4(2.9)$ & $1.7(1.2)$ & $2.0(2.4)$ \\
$\mathrm{Fe}\left({\left.\mu \mathrm{L} \mathrm{L}^{-1}\right)}^{289.9(188.8)}\right.$ & $253.4(155.7)$ & $199.2(145.6)$ & $0.9(0.8)$ & $0.7(0.8)$ \\
\hline
\end{tabular}

Title Page

Abstract

Introduction

Conclusions

References

Tables

Figures

14

$>$ I

4

Back

Close

Full Screen / Esc

Printer-friendly Version

Interactive Discussion 
Table 2. Geladaindong and Everest ${ }_{M} B C$ and $F e\left(\mu \mathrm{L}^{-1}\right)$ average and (median) concentrations based on data resampled to 3 samples/year from 1860-1982 (the period of overlap between the two records), average snow accumulation rate at each site (cm water equivalent/year), and $\mathrm{BC}$ and Fe flux (accumulation rate $x$ average (or median) concentration). The Everest data is from Kaspari et al. (2011), however concentrations reported here have been corrected for nebulizer losses based on Aquadag standards.

\begin{tabular}{|c|c|c|c|}
\hline & Geladaindong (5750 m) & Everest $(6518 \mathrm{~m})$ & Geladaindong/Everest \\
\hline $\mathrm{M}^{\mathrm{BC}}\left(\mu \mathrm{gL}^{-1}\right)$ & $2.1(1.3)$ & $0.6(0.3)$ & $3.5(4.3)$ \\
\hline $\mathrm{Fe}\left(\mu \mathrm{gL}^{-1}\right)$ & $255(176)$ & $107(73)$ & $2.4(2.4)$ \\
\hline $\begin{array}{l}\text { accumulation rate } \\
\left(\mathrm{cm} \text { w.e. } \mathrm{yr}^{-1}\right)\end{array}$ & 30 & 50 & 0.60 \\
\hline $\begin{array}{l}{ }_{M} B C \text { flux } \\
\left(\mathrm{ng}_{M} \mathrm{BC} \mathrm{cm}^{-2} \mathrm{yr}^{-1}\right)\end{array}$ & $63(39)$ & $30(15)$ & $2.1(2.6)$ \\
\hline $\begin{array}{l}\text { Fe flux } \\
\text { (ng Fe } \mathrm{cm}^{-2} \mathrm{yr}^{-1} \text { ) }\end{array}$ & $7650(5280)$ & $5350(3650)$ & $1.4(1.5)$ \\
\hline
\end{tabular}

Black carbon

concentrations from

a Tibetan Plateau ice

core

M. Jenkins et al.

Title Page

Abstract

Introduction

Conclusions

References

Tables

Figures

14

$>$ I

$<$

Back

$\checkmark$

Full Screen / Esc

Printer-friendly Version

Interactive Discussion 


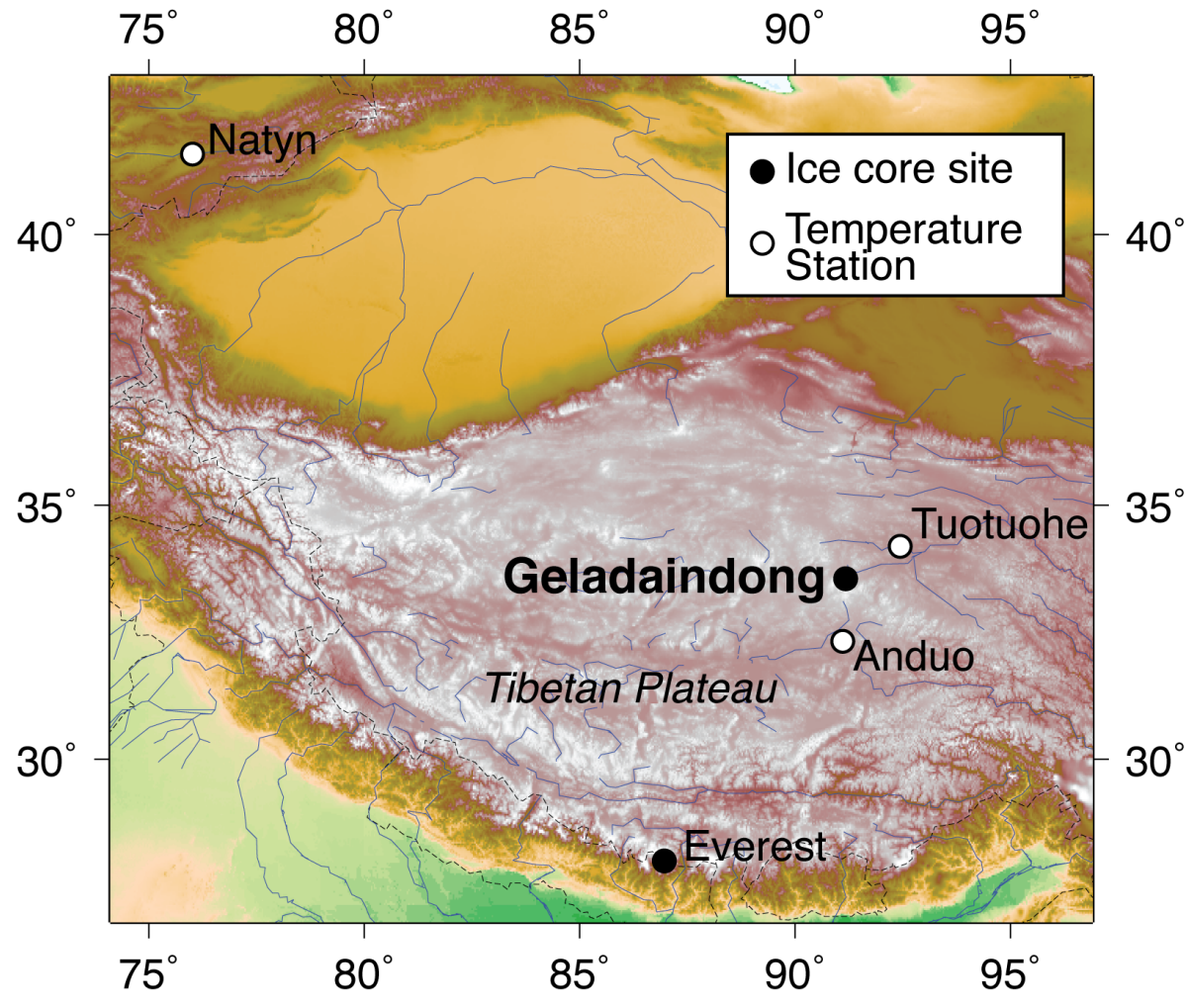

Fig. 1. Map showing the location of the Geladaindong and Everest ice core sites, and temperature stations discussed in the text.

\section{TCD}

$7,4855-4880,2013$

Black carbon concentrations from

a Tibetan Plateau ice core

M. Jenkins et al.

\section{Title Page}

\section{Abstract}

Conclusions

\section{Tables}

14

4

Back 

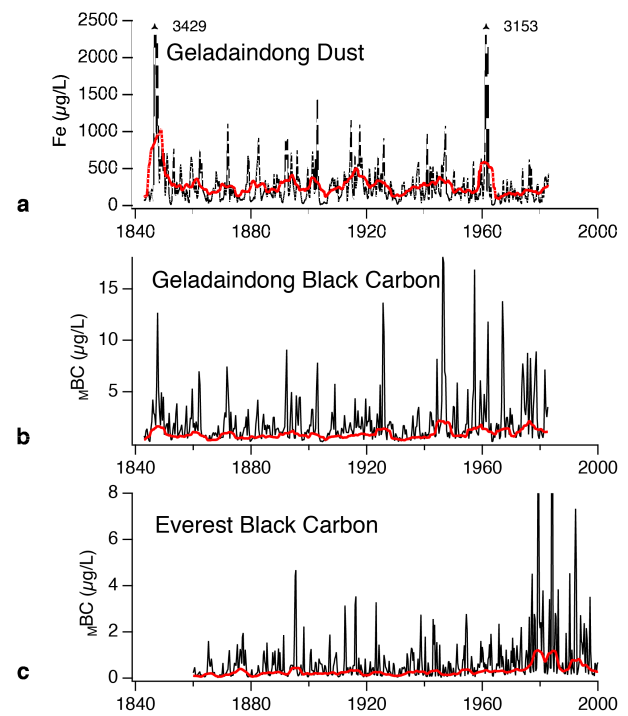

\section{Black carbon}

concentrations from

a Tibetan Plateau ice

core

M. Jenkins et al.

Title Page

Abstract

Conclusions

Tables

14

Back
Introduction

References

Figures

$>1$

$\triangleright$

Close

Fig. 2. (a) Geladaindong Fe (used as a proxy for dust), (b) Geladaindong ${ }_{M} B C$ and (c) Everest ${ }_{M} B C$ (Kaspari et al., 2011; note the concentrations plotted here have been corrected for nebulizer losses) smoothed with a 15 point boxcar (red). (d) Black carbon emissions from energy related combustion (Bond et al., 2007). The regional black carbon emissions (red) are a summation of emissions from East Asia, the Former USSR, Eastern Europe, South Asia, and the Middle East.

\section{Full Screen / Esc}

Printer-friendly Version 


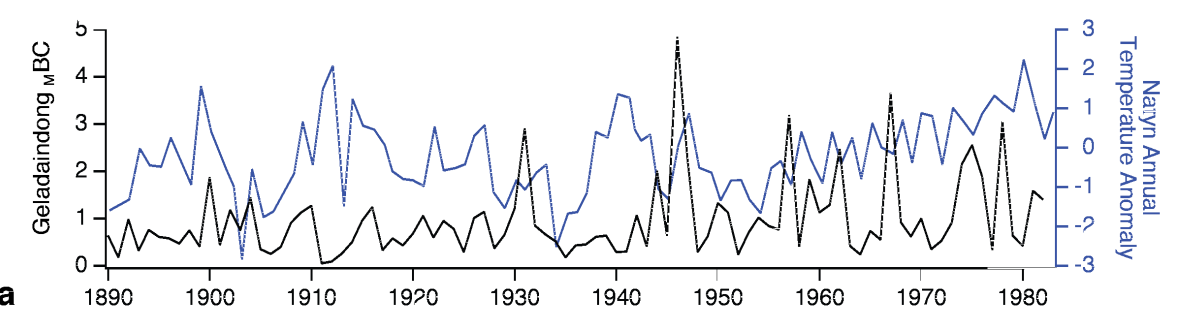

TCD
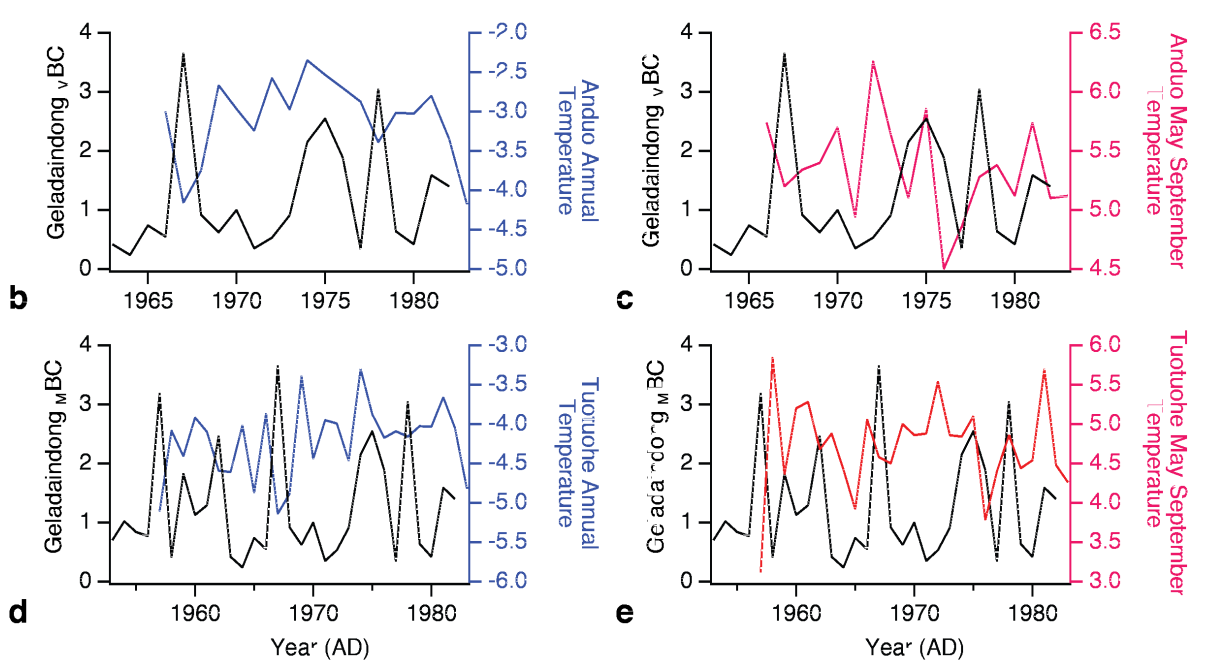

Fig. 3. Geladaindong ${ }_{M} B C$ and (a) Natyn annual mean temperature anomaly (relative to 1950 1979 reference period) from Liu and Chen (2000), (b) Anduo annual temperature, (c) Anduo May-September temperature, (d) Tuotuohe annual temperature, and (e) Tuotuohe MaySeptember temperature.

\section{Black carbon concentrations from a Tibetan Plateau ice core}

M. Jenkins et al.

Title Page

Abstract

Introduction

Conclusions

References

Tables

Figures

14

$>$ I

4

Back

Close

Full Screen / Esc

Printer-friendly Version

Interactive Discussion 